\title{
Study of Some Transition Metal Complexes of Schiff Base: Thermodynamic and Kinetic Aspects
}

\author{
Surendra Prasad Singh* \\ Department of Chemistry, Amrit Campus, Tribhuvan University, Kathmandu
}

\begin{abstract}
$\mathrm{Cu}(I I), \mathrm{Ni}(I I), \mathrm{Co}(I I), \mathrm{Fe}(I I I)$ and $\mathrm{Mn}(I I)$ complexes with Schiff base are prepared by condensation of dihydroacetic acid with o-toluidine. The ligand acts as bidentate molecule. The kinetic parameters for their decomposition have been evaluated by Coats-Redfern method from TG data. The values of kinetic and thermodynamic parameters are comparable, and the decomposition follows a reaction mode.
\end{abstract}

\section{Introduction}

Metal complexes of various Schiff bases have been the subject of intensive research ${ }^{1,2}$ but comparatively little attention has been given to the Schiff bases derived from dihydroacetic acid and no report is available for the kinetic parameters of such complexes. The present communication deals with the synthesis, thermal degradation and evaluation of kinetic parameters of complexes of $\mathrm{Cu}(\mathrm{II}), \mathrm{Ni}(\mathrm{II})$, $\mathrm{Co}(\mathrm{II}), \mathrm{Fe}(\mathrm{III})$ and $\mathrm{Mn}$ (II) with Schiff base derived from dihydroacetic acid and o-toluidine.

\section{Experimental Methods}

The Schiff base was synthesised by adding an ethanolic solution of the appropriate amine (o-toluidine) to an ethanolic solution of lactone (dihydroacetic acid) in 1:1 molar ratio and refluxing the resulting mixture on an RML Rotamantle for 4-6 h. The white product was crystallised from ethanol. Purity of the compound was checked by TLC.

The metal complexes were synthesised by adding a methanolic solution of the appropriate metal salt $\mathrm{MCL}_{2} \cdot \mathrm{xH}_{2} \mathrm{O}(0.02 \mathrm{~mol})$ to a methanolic solution of Schiff base (DHA-o-toluidine) $(0.02 \mathrm{~mol})$ and the reaction mixture was refluxed on an RML Rotamantle for $2 \mathrm{~h}$. To the cold solution, $10 \%$ alcoholic ammonia solution was added drop wise till the precipitate was formed. The complexes of different metals were precipitated at different $\mathrm{pH}$. The precipitate of complex was filtered in hot condition, washed with hot methanol followed by petroleum ether $\left(40-60^{\circ} \mathrm{C}\right)$. The metal complexes were dried under reduced pressure over anhydrous $\mathrm{CaCl}_{2}$ in a desiccator.

The TG curves were recorded at RSIC, Chennai, with heating rate $10^{\circ} \mathrm{C}$ per min from room temperature to $1000^{\circ} \mathrm{C}$ in nitrogen atmosphere.

\footnotetext{
${ }^{*}$ Corresponding author
} 


\section{Results and Discussion}

The analytical data and physico-chemical data of the ligand and complexes are presented in Table- 1 . The conductivity data of all complexes (in 10-4 M DMSO) show the non-electrolytic nature of these complexes.

Table 1: Physical data and magnetic data of the complexes

\begin{tabular}{llcc}
\hline \multicolumn{1}{c}{ Compound* } & Colour & $\begin{array}{l}\text { m.p. } \\
\left({ }^{\circ} \mathrm{C}\right)\end{array}$ & $\begin{array}{c}\mu_{\text {eff }} \\
(\text { B.M. })\end{array}$ \\
\hline DHA-2-methyl phenyl anil $\left(\mathrm{L}_{1}\right)$ & White & 164 & - \\
{$\left[\mathrm{Cu}(\mathrm{II})-\left(\mathrm{L}_{1}\right)_{2}\right]$} & Green & 252 & 1.81 \\
{$\left[\mathrm{Ni}(\mathrm{II})-\left(\mathrm{L}_{1}\right)_{2}\right]$} & Brown & $>300$ & 3.31 \\
{$\left[\mathrm{Co}(\mathrm{II})-\left(\mathrm{L}_{1}\right)_{2}\right]$} & Green & $>300$ & 4.45 \\
{$\left[\mathrm{Fe}(\mathrm{II})-\left(\mathrm{L}_{1}\right)_{2}\right]$} & Brown & 248 & 5.59 \\
{$\left[\mathrm{Mn}(\mathrm{II})-\left(\mathrm{L}_{1}\right)_{2}\right]$} & Black & $>300$ & 5.13 \\
\hline
\end{tabular}

*All compounds gave satisfactory $\mathrm{C}, \mathrm{H}$ and $\mathrm{N}$ analysis.

The infrared spectra of the ligands show a broad weak band around $2600-2400 \mathrm{~cm}^{-1}$ attributed to intramolecular hydrogen bonding ${ }^{3}$. The $\mathrm{O}-\mathrm{H}^{\cdots} \mathrm{N}$ stretching at $2600-2400 \mathrm{~cm}^{-1}$ observed in the ligand is absent in all the complexes which confirms the deprotonation of enolic $\mathrm{O}-\mathrm{H}$ and coordination of oxygen with metal ions. This is further supported by an upward shift $\mathrm{v}(\mathrm{C}-\mathrm{O})\left(1250 \mathrm{~cm}^{-1}\right)$ the extent of $20-30 \mathrm{~cm}^{-}$ ${ }^{1}$ in all the complexes. Infrared spectrum of ligand shows a strong band at $1670 \mathrm{~cm}^{-1}(\mathrm{C}=\mathrm{N})$ which is shifted to lower frequency region $\left(1650 \mathrm{~cm}^{-1}\right)$ in the complexes indicating the participation of azomethine group in chelation. The new bands at $580 \mathrm{~cm}^{-1}$ and $460 \mathrm{~cm}^{-1}$ in the metal complexes have been assigned to $\mathrm{v}(\mathrm{M}-\mathrm{O})$ and $\mathrm{v}(\mathrm{M}-\mathrm{N})$ mode respectively ${ }^{4}$.

On the basis of magnetic moment value (Table-1) octahedral geometry for compounds 1-4 and tetrahedral geometry for compound 5 are suggested.

\section{Thermal Studies}

[Cu(II)-( $\left.\mathbf{L}_{1}\right)_{2}$ ] complex: TG curve of $\mathrm{CU}(\mathrm{II})-\left(\mathrm{L}_{1}\right)_{2}$ complex shows that there is no weight loss up to $260^{\circ} \mathrm{C}$ indicating the absence of lattice or coordinated water. Therefore, the complex exhibits high thermal stability and decomposes at $>300^{\circ} \mathrm{C}$. The thermogram shows one step exothermic peaks at $314.6^{\circ} \mathrm{C}$ which indicate the decomposition temperature of $\mathrm{Cu}(\mathrm{II})$ complex. Endothermic peak observed in differential thermal curve around $439.9^{\circ} \mathrm{C}$ and $589.7^{\circ} \mathrm{C}$ may be due to decomposition of the organic ligand and subsequent slow oxidations ${ }^{5}$. The thermogravimetric curve attains stability at $700^{\circ} \mathrm{C}$ and the horizontal line has been observed after $700^{\circ} \mathrm{C}$ in the complex and the residue corresponds to the respective metal oxide.

\section{[Ni(II)-( $\left.\left.\mathrm{L}_{1}\right)_{2}\right]$ complex}

A careful analysis of thermogram indicates that the complex is stable up to $280^{\circ} \mathrm{C}$. The metal chelate follows single step decomposition. The thermogravimetric curve shows a single exothermic peak at $343.5^{\circ} \mathrm{C}$ which indicates decomposition temperature of the metal chelate and shows absence of lattice or coordinated water. Finally $\mathrm{NiO}$ is obtained as the end product. 


\section{J. Nepal Chem. Soc., Vol. 38, 2018}

\section{[Co(II)-( $\left.\left(\mathrm{L}_{1}\right)_{2}\right]$ complex}

The observed weight loss within $40-105^{\circ} \mathrm{C}$ temperature range could be correlated with the loss of water of crystallisation or lattice water ${ }^{6}$. The second step was encountered at $240^{\circ} \mathrm{C}$ where the organic constituents of the complex start breaking and the decomposition at $337^{\circ} \mathrm{C}$ shown in thermogravimetric curve is supported by two endothermic peaks at 312 and $486^{\circ} \mathrm{C}$ in differential thermal curve. The formation of metal oxide is observed at $697^{\circ} \mathrm{C}$.

\section{$\left[\mathrm{Fe}(\mathrm{III})-\left(\mathrm{L}_{1}\right)_{2}\right]$ complex}

The thermogravimetric curve of $\mathrm{Fe}(\mathrm{III})$ complex shows as exothermic peak at $87.9^{\circ} \mathrm{C}$ which corresponds to water of crystallisation ${ }^{7}$. However, the temperature $274^{\circ} \mathrm{C}$ may be the decomposition temperature of organic matter and the exothermic peak at $328^{\circ} \mathrm{C}$ indicates decomposition temperature of the complex. $\mathrm{FeO}$ is obtained as the end product at $554^{\circ} \mathrm{C}$.

\section{$\left[\mathrm{Mn}(\mathrm{II})-\left(\mathrm{L}_{1}\right)_{2}\right]$ complex}

The thermogravimetric curve of $\mathrm{Mn}$ (II) complex shows a weight-loss by a weak exothermic peak at $61^{\circ} \mathrm{C}$, indicating the presence of lattice or water of crystallisation. The organic pan completely decomposing in the range $231-289^{\circ} \mathrm{C}$ was supported by differential thermal curve. Finally, $\mathrm{MnO}$ is obtained at $621^{\circ} \mathrm{C}$.

Thermal studies indicate that all the metal complexes do not contain coordinated water and that they are thermally quite stable. Decomposition of all the complexes started at relatively higher temperature and was completed above $650^{\circ} \mathrm{C}$ and the weights of the residue correspond to the formation of metal oxide. The thermal behaviours of $\mathrm{Cu}(\mathrm{II})$ and, $\mathrm{Ni}$ (II) complexes are almost same while the others differ from-them.

\section{Kinetic Parameters for Thermal Decomposition}

The fractional weight loss $(\alpha)$ and the corresponding $(1-\alpha)$ n have been calculated from TG curves at different temperatures, where $\mathrm{n}$ depends upon the reaction model and $\alpha=\left(\omega_{t}-\omega_{f}\right) /\left(\omega_{o}-\omega_{f}\right)$. The T vs. curves were constructed on the basis of thermogravimetric data for all the five complexes was subjected to non-isothermal kinetic studies. The weighed least-square method (LSM) was used for obtaining best-fit linear plots by applying the data of various equations and thus the kinetic parameters were evaluated. The values of slope, intercept and energy of activation were obtained from plots. The value of slope, intercept and energy of activation were obtained from plots. The value of frequency factor (Z) was evaluated using eqn. (1) for CoatsRedfern method and the entropy of activation was calculated using eqn. (2).

$$
\text { Intercept }=\log \left(\mathrm{ZR} / \beta \mathrm{E}_{\mathrm{a}}\right)
$$

$$
\Delta \mathrm{S}=2.300 \mathrm{R} \log \mathrm{Zh} / \mathrm{KT}_{\mathrm{m}}
$$

where $\mathrm{K}$ is the Boltzmann constant, $\mathrm{h}$ the Planck's constant, $\beta$ the, rate of heating, $\mathrm{R}$ the molar gas constant and $\mathrm{T}_{\mathrm{m}}$ the peak temperature.

The values of $E_{a}, Z$ and $\Delta S$ are given in Table-2 and the apparent order of the reaction is one. The values of kinetic parameters have been calculated by Coats-Redfern method ${ }^{8}$. The higher value of activation energy suggests the higher stability. In the present study, the numerical values of activation 
energy $\left(E_{a}\right)$, frequency factor $(Z)$ and entropy of activation $(\Delta S)$ indicate the smoothness of the feasibility and reaction rate of the initial reactants and intermolecular stage compounds.

Table-2: Thermal kinetic parameters of the complexes of $\mathrm{Cu}(\mathrm{II}), \mathrm{Ni}(\mathrm{II}), \mathrm{Co}(\mathrm{II}), \mathrm{Fe}(\mathrm{III})$ and $\mathrm{Mn}$ (II) by coats-redfern method

\begin{tabular}{lcccc}
\hline Compound No. & $\begin{array}{c}\text { Decomposition } \\
\text { stage/temp. }\left({ }^{\circ} \mathrm{C}\right)\end{array}$ & $\begin{array}{c}\mathrm{E}_{\mathrm{a}} \\
\left(\mathrm{kJ} \mathrm{mol}^{-1}\right)\end{array}$ & $\begin{array}{c}\mathrm{Z} \\
\left(\mathrm{S}^{-1}\right)\end{array}$ & $\begin{array}{c}-\Delta \mathrm{S} \\
\left(\mathrm{kJ} \mathrm{mol}^{-1}\right)\end{array}$ \\
\hline$\left[\mathrm{Cu}(\mathrm{III})-\left(\mathrm{L}_{1}\right)_{2}\right]$ & $\mathrm{I} / 314$ & 33.26 & 326 & 202.40 \\
{$\left[\mathrm{Ni}(\mathrm{II})-\left(\mathrm{L}_{1}\right)_{2}\right]$} & $\mathrm{I} / 343$ & 12.31 & 204 & 206.00 \\
{$\left[\mathrm{Co}(\mathrm{II})-\left(\mathrm{L}_{1}\right)_{2}\right]$} & $\mathrm{I} / 240$ & 8.75 & 117 & 209.00 \\
& $\mathrm{II} / 337$ & 32.21 & 323 & 202.86 \\
{$\left[\mathrm{Fe}(\mathrm{III})-\left(\mathrm{L}_{1}\right)_{2}\right]$} & $\mathrm{I} / 274$ & 4.38 & 62 & 215.84 \\
& $\mathrm{II} / 328$ & 10.44 & 152 & 209.01 \\
{$\left[\mathrm{Mn}(\mathrm{II})-\left(\mathrm{L}_{1}\right)_{2}\right]$} & $\mathrm{V} / 256$ & 20.88 & 248 & 203.80 \\
& $\mathrm{II} / 449$ & 75.35 & 533 & 214.00 \\
\hline
\end{tabular}

The negative values of entropy of activation indicate that the activated complexes have a more ordered or more rigid structure than the reactants.

Kinetic parameters for these compounds have been determined individually at the first and second decomposition stages. Usually the first decomposition temperature lies in the range $240-343^{\circ} \mathrm{C}$ and the second one in the range $328-449^{\circ} \mathrm{C}$. The order of thermal stability of compounds comes to be $2>1>4>5>3$ $\left(343>314>274>256>240^{\circ} \mathrm{C}\right.$ ) (on the basis of first decomposition stage) and $5>3>4$ (on the basis of second decomposition stage). The order of stability of the compounds on the basis of the values of activation energy can be set as $1>5>2>3>4$ (for first step) and $5>3>4$ (for second step). The variation in the trend might be interpreted to be due to some intermolecular interactions (structural as well as electronic) occurring therein. These are besides several experimental factors? .

\section{Acknowledgement}

I am highly obliged to Prof Ramesh Chandra, head of Chemistry Dept, Delhi University and Dr. S.N. Thakur and team for valuable suggestions and providing me technical and lab facilities.

\section{References}

1. S.F. Tan and K.P. Ang, Trims. Met. Chem., 9, 390 (1984); 13,64(1988).

2. N.R. Rao and M.C. Ganorkar, Indian J. Chem., MA, 877 (1985); 26A, 887 (1987); 27A, 52 (1988)..

3. T.K. Chondhekar and D.O. Khanolkar, Indian J. Chem., 25A, 868 (1986).

4. A.P. Mishra and Mahima Khare,J. Indian Chem. Soc., 77, 367 (2000).

5. N.S. Bhave and R.B. Kharat, J. Indian Chem. Soc., 58, 1194 (1981).

6. P.R. Shukla, V.K. Singh 'and J. Bhargava, J. Indian Chem. Soc., 59, 620 (1982).

7. A.V. Nikolaev, V.A. Langvienko and L.1. Myachina, Thermal Analysis, Vol. 2, Academic Press, New York, p. 779 (1969).

8. A.W. Coats and J.P. Redfern, Nature, 201,68 (1964).

9. A.P. Mishra, V.Vyas and D. Pandey, Indian J. Chem., 37,927 (1998). 